G7

\section{ZONED PYROXENES IN ULTRAMAFIC ROCKS}

E. JAGOUTZ, J. HUTH, and B. SPETTEL

Max-Planck-Institut, Abt. Kosmochemie, D-6500 Mainz, W-Germany

The pyroxenes from some lherzolites in alpine type ultramafic intrusions are compositionally zoned. The zonation is more pronounced in $c p x$ than in opx. The cores of pyroxene porphyroblasts are richer in Al than the rims. A similar trend is observed for $\mathrm{Na}$ in $\mathrm{Cl}$ inopyroxenes. In some $\mathrm{Ca}-$ ses zonation of pyroxenes is also found in ultramafic nodules from alkali basalts. Sometimes reversed zoning occurs. Neoblasts commonly have the same composition as the rims of the porphyroblasts.

In order to study the behaviour of trace elements we have separated by handpicking porphyroblastic clinopyroxenes from a lherzolite from Lherz. The surfaces of these pyroxenes where painted with ink and then ground to less than $200 \mathrm{mi}-$ crons. With this method rims and cores of the pyroxenes could be distinguished and separated. The two separates were analysed by INAA. A lower $\mathrm{Na}$ content of the rim fraction may indicate loss of jadeite component. This would also explain the parallel depletion of $\mathrm{Cr}$ and possibly the heavy REE in that fraction (1). Because of slight differences in REE contents between the two fraction we expect differences in $\mathrm{Sr}$ - and $\mathrm{Nd}$-isotopes. These measurements are in progress. The resuits will give us a tool to estimate the time of uplift of ultramafic complexes.

Lit. E. Jagoutz et al. In: The Mantle Sample: Inclusions in Kimberlites and Other Volcanics (F.R. Boyd and H.O.A. Meyer, eds.), p. 382. Amer. Geophys. Union, Washington, D.C.

\section{G8}

\section{CHEMICAL DISEQUILIBRIUM IN SPINEL-LHERZO- LITES FROM ARIEGE (FRENCH PYRENEES).}

\section{F. CONQUERE, J. FABRIES}

Labo. Mineralogie, Musèum d'Histoire Naturelle, 61, rue Buffon, 75005 Paris, France.

Detailed microprobe analyses have been performed in 45 spinel-peridotite samples from the Lherz and Freychinede ultramafic bodies representative of the exceptionally-wide modal and chemical variation found in these bodies.

Regardless of this between-sample variation, in each individual sample, whereas olivine composition is invariable, spinels and pyroxenes, especially orthopyroxenes, show irregular and sometimes wide chemical variations from nearly a constant composition in the core of the porphyroclasts to their margins and to the coexisting neoblasts. In pyroxenes, Al and, to a lesser extent, $\mathrm{Cr}$ and $\mathrm{Na}$ contents decrease. Spinels display the strongest variations, due to the combination of $\mathrm{FeAl}_{2} \mathrm{O}_{4}$ enrichment with a later $\mathrm{FeCr}_{2} \mathrm{O}_{4}$ increase.

By applying various geothermometers, two groups of temperatures have been estimated at $900^{\circ}-950^{\circ} \mathrm{C}$ and $700^{\circ}-750^{\circ} \mathrm{C}$ respectively. The first represents the final equilibrium state reached during the main stage of deformations and recrystallizations which occurred in the uppermost mantle $(13-15 \mathrm{~Kb})$ in all Pyrenean lherzolitic bodies. The second is believed to represent a partial heterogeneous reequilibration which occurred during the subsequent ascent of these ultramafic slices and their emplacement in the lower crust before their solid extrusion in Cretaceous 1 imestones.
The present disequilibrium observed in these ultramafic complexes strongly contrasts with the chemical homogeneity which seems to exist in most spinel-peridotite xenoliths whatever their textures and equilibrium temperatures $\left(900^{\circ}\right.$ to $1200^{\circ} \mathrm{C}$ ).

\section{G9}

THE ULTRAMAFIC-GRANULITIC ASSOCIATIONS: AN INDICATION OF PALEO-MOHO DISCONTINUITIES.

\section{VIELZEUF and J. KORNPROBST}

Département de Géologie, LA 10 et IOPG - 5, rue Kessler 63038 Clermont-Fd

The very high nressure parageneses of mafic-ultramafic associations and the comon field relationships of these rocks with crustal granulite-facies rocks surgest a two stages emplacerient nodel for such peridotitic bodies.

A- The first staje could be related to convective processes involving "diapiric" uprise and moderate partial melting of a fragment of the mantle. The afic-ultranafic associations re-equilibrated at depth near the subcontinental ivolio P.T. conditions.

- The second stare involves the emplacenent to their present environment of the ultramafic bodies tozether with the deep seated continental crustal rocks as a result of two different processes :

1- Emplacenent along passive margins during extensional tectonic rezi.ue; creation of oceanic crust involves a preliminary crustal thinning and occurence of the rantle at shallow depth on each bank of the oceanic area. This situation is observed alont, the ralicia Bank.

2- The emplacenent as a result of a compressive stage after crustal thinning may lead to two different situations :

a) The previous structural relationstips between ultranafic (mantle) and "ranulitic (crustal) rocks are nore or less preserved, as shown in the Ivrea zone and in the lieni-bousera and Ronda area ; these concordant units are overthrust upon hore superficial units pointing out mega-dislocations involving the whole upper mantle/lower crust pile.

b) The previous upper mantle/lower crust structural relationstips were disrupted : ultrailafic and sranulitic rocks occur as scattered bodies along deep crustal transcurrent lineailents. This situation has been recosnized in the nort!ern pyrences and alon; the Southern border of the :ifo- abvleali icelt.

\section{G10}

KIMBERLITES IN THE EASTERN UNITED STATES: LOCATION AND DEPTHS OF ORIGIN RELATED TO MID-ATLANTIC TECTONISM.

\section{LAWRENCE A. TAYLOR and ROBERT H. HUNTER}

Department of Geological Sciences, University of Tennessee, Knoxville, TN 37996, USA.

Early Mesozoic, diatreme- and hypabyssal-facies kimberlites in the Valley and Ridge and the Appalachian Plateau Provinces of the Eastern USA record mantle perturbations associated with the early phases of MidAtlantic rifting.

The depth of generation of the kimberlite melts seems to correlate with the distance from the rift location. Within the Valley and Ridge Province (Tennessee and Virginia), the kimberlites are highly 
altered and represent diatreme-facies with considerable volatile autometasomatism. To the west in the Appalachion Plateau (E. Kentucky and S.W' Pennsylvania), fresh rock contains abundant peridotite xenoliths. Garnet Iherzolites yield pressures equivalent to depths of $150 \mathrm{~km}$ and $160-170 \mathrm{~km}$, respectively. Megacryst chemistry records near-isobaric fractionation over $\sim 200^{\circ} \mathrm{C}\left(1350-1150^{\circ} \mathrm{C}\right)$. Th is is like the steep, inflected limbs of the Lesotho-type geotherms. Further into the Plateau, in New York State, megacrysts record a $100 \mathrm{~km}$ depth and 1100 $1050^{\circ} \mathrm{C}$. Spinel megacrysts and spinel peridotite xenoliths also represent a shallower origin. Eclogite xenoliths in the New York and Tennessee kimberlites indicate thir o be a widespread component of the lower crust in the E. USA.

The occurrences in New York lie along a N-S joint pattern, that in S.W. Pennsylvania runs for $4-5 \mathrm{~km}$ along a NW-SE fault, transform to the prevailing structure (perhaps in a manner analogous to similar occurrences related to South-Atlantic rifting, e.g., Marsh, 1973). The ages of the southern occurrences are older than those in the North, reflecting progressive northerly rifting with time. All of the features discussed above can be explained by the prevailing tectonic regime for the Eastern United States during Early - Mid Mesozoic times.

\section{G11}

\section{TEMPORAL AND SPATIAL PATTERNS OF ALKALI CONTINENTAL VOLCANISM: A TEST OF THE HOTSPOT CONCEPT}

\section{S.T. CROUGH}

Department of Geosciences. Purdue University, West Lafayette IN 47907

The origin of kimberlite magma is investigated by compiling the known ages and locations of kimberlites, carbonatites, and other alkali continental intrusions. Because different proposed theories of origin make somewhat different predictions concerning eruption timing and location, these data help constrain speculation. The simplest model to test is the hotspot theory which predicts that the data must be selfconsistent with plate motion over a set of mutually fixed magma sources. Other testable models include the reactivated fracture hypothesis which predicts linear patterns with uniform ages and the asthenospheric shear model which predicts craton-wide volcanism at times of rapid plate movement.

The post-Paleozoic igneous record of the Atlantic-bordering continents is found to be most consistent with the fixed hotspot concept. The same absolute plate motions which explain the majority of known seamount ages on the Atlantic ocean floor by fixed hotspots also explain most of the continental intrusions, including kimberlites. The reactivated fracture hypothesis is less satisfactory because many of the volcanic lineaments have demonstrable age progressions along their length. The shear melting model seems inconsistent with the great variety of ages observed within single cratons, although the data do suggest a relative peak of volcanic activity during the cretaceous interval of rapid seafloor spreading.

\section{G12}

MINERALOGY AND COMPOSITION OF ABYSSAL AND ALPINE-TYPE PERIDOTITES

\section{H.J.B. DICK,}

Department of Geology \& Geophysics, Woods Hole Oceanographic Institution, Woods Hole Massachusetts 02543
Abyssal and alpine-type peridotites share the mineralogic and compositional features of the depleted resijues of mantle melting and magma generation. Within the somewhat limited compositional spectrum of mantle peridotites, however, there are systematic differences between these different peridotite types which reflect melting in very different physical environments. Abyssal peridotite localities are characterized by very restricted mineral compositions and a relatively high abundance of modal diopside. It is apparent that melting of abyssal peridotites in general does not procede beyond the 4-phase field $01-E n-D i-S p$, and accordingly melt compositions are constrained by the four phase pseudo invarient point.

In contrast, alpine-type peridotites are frequently highly depleted compared to abyssal peridotites, and many have lower Di/En ratios. Frequently they have highly $\mathrm{Mg}, \mathrm{Al}$-poor, and $\mathrm{Cr}$-rich mineral compositions lying entirely outside the range for abyssal peridotites. In addition, many alpine-type peridotites show very large local variations in degree of melting, often with large ranges of mineral compositions. It is evident that most alpine-type peridotites have meltad well into the three phase fie?d 0l-En-Sp under very different conditions than melting of abyssal peridotites.

These differences between abyssal and some alpine peridotites we attribute to hydrous remelting of abyssal peridotites in arc environments and their eventual emplacement there as ophiolite complexes. Thus many ophiolite complexes contain mantle peridotites ranging in composition from the abyssal mantle to the highly depleted residues of the generation of arc-magmas; possibly reflecting local variations in the availability of water during the last stages of melting.

\section{G13}

\section{MAGMATIC AND TECTONIC EVENTS IN AN OCEA- NIC DIAPIR.}

\section{OHNENSTETTER}

Laboratorre de Pètrologie. Unıv Nancy I. B.P. 239. 54506 Vandøeuvre les Nancy.

The lherzolitic massif from Monte Maggiore, Northern Corsica, France $(3 \times 1.5 \mathrm{~km})$ which beloris to an ophiolitic complex rests tectonically on : pile of thrust slabs. Structural, petrological ard mineralogical studies have been engaged to determine the chronology of coupled magratic anc tectonic events during diapiric uprise of an oceanic mantle.

The oldest relict mantle, consists of layered and folded $\mathrm{Cpx}-\mathrm{rich}$ peridotites evolving from $\mathrm{Sp}$ free rocks to Sp-bearing ones. They have suffered 1 imited or extensive partial fusion events, resfectively initiated by pervasive injections of limited amounts of alkali-basaltic liquids or larger volumes of 01-rich tholeiitic magma.

Circulation of alkali-rich liquids favoring the 1-ropagation of cracks have led to local enrichmert of $\mathrm{Al}, \mathrm{Ti}, \mathrm{Na}, \mathrm{K}, \mathrm{P}$ and $\mathrm{Zr}$ as testified by the composition of the phases and the thermal disequilibrium. A mappable layered P1-rich peridotite, towards the center of an ovoid lens of depleted peridotites $(0.8-0.5 \mathrm{~km})$ indicate fractionaticr: of 1-Sp-Opx-Cpx and P1 during magma ascent.

Iruring progressive uprise of the mantle, Opx cisappears as a liquidus phase in the least evclvec 